\title{
Chief Justice Warren and Labor Law
}

\author{
Sam Kagel* and Virginia B. Smith**
}

SINCE EarL Warren assumed the position of Chief Justice of the Su$\mathcal{O}$ preme Court in 1953 he has written relatively few opinions in the labor law area. But from some of those that he did write, together with his voting record on others, a pattern of some of his views on labor law may be discerned.

Contrary to statements or inferences that sometimes are made, the Chief Justice is not "pro-labor." Nor is he "anti-labor." His approach to labor law is guided by certain principles which can best be noted in cases involving (1) a determination of the degree to which Congress has pre-empted the field of labor relations; (2) the application of the first amendment to labor cases; and (3) the Court's efforts to develop a body of law on the nature of the collective bargaining process and the collective bargaining agreement.

We are concerned here with the extent to which the Chief Justice has contributed to the development of these aspects of labor law and how his contributions have been shaped by general principles applicable to all fields of law rather than by any preconceived notions or bias on labor relations.

I

PRE-EMPTTON

In the field of labor law Chief Justice Warren is a complete pre-emptionist-a federahist. An early use of the term pre-emption in American law referred to the right given settlers on public lands to purchase them at a limited price to the exclusion of all others. Pre-emption is thus the process of appropriating land, or goods, or some right to the exclusion of others. ${ }^{2}$

In labor law pre-emption is the term given to the Supreme Court doctrine which ousts state courts of jurisdiction to hear cases falling within the scope of federal labor legislation. Congress, by enacting the National Labor Relations Act in $1935^{3}$ and its major amendments in $1947^{4}$ and $1959^{5}$ "pre-

* Member of the California Bar, Professor of Law, University of California School of Law, Berkeley.

** Member, California and Washington Bars.

1 In a box score on the voting record of Supreme Court Justices on labor cases in 1959-60, Paul Hays of Columbia University lists Chief Justice Warren on the "labor side" of the case in 18 out of 18 cases. Hays, The Supreme Court and Labor Law, October Term, 1959, 60 Conum.

L. REv. 901 n.1 (1960).

249 C.J. 1321 (1930).

349 Stat. 449 (1935).

461 Stat. 136 (1947).

573 Stat. 519 (1959). 
empted" a certain part of the labor relations field, assigning its regulation exclusively to the National Labor Relations Board. The question that has plagued the Court is that of what "metes and bounds" to set on the field over which Congress has granted the National Labor Relations Board "squatters rights."

The Chief Justice has consistently viewed it as a broad area encompassing all that conduct which could arguably come within the explicit or implicit scope of the NLRA section $7,{ }^{7}$ the policy section and section $8,{ }^{8}$ the regulatory or remedy section. He has further strengthened the Board's position by emphasizing its right in the first instance to determine whether the particular matter comes within the boundaries of this pre-empted area. But he has reserved to the state an "easement" cutting across this field within which the states are to protect and maintain the local peace.

Chief Justice Warren's pre-emption doctrine in the field of labor law is based upon the fact that Congress enacted a compreliensive scheme dealing with labor relations and entrusted the administration of this overall plan to the NLRB. Other Justices have more narrowly and less defimitely drawn the boundaries, holding in favor of joint occupancy over large areas that he would pre-empt. These Justices hold that the right of coexistence is cut off when there is conflict between Board remedies and state remedies in any given situation, or, in the broad sense, when there is a conflict in purpose between state and federal policy. ${ }^{9}$ Thus the "metes and bounds," as these Justices survey the field, would fluctuate depending upon the facts of each case.

The Chief Justice's enunciation of his complete pre-emption approach will be noted as we examine some of the cases in the labor relations field. In a 1957 decision, International Ass' $n$ of Machinists $v$. Gonzales, ${ }^{10}$ the Court upheld a judgment of a state court against the Machinists' Union for lost wages as well as for physical and mental suffering. In a dissenting opimion the Chief Justice said:

The principles declared in Garner v. Teamsters C. \& H. Local Union ... were not the product of inperfect consideration or untried hypothesis. They comprise the fundainental doctrines that have guided this Court's pre-

$B$ "[T]he areas . . . pre-empted ... are not susceptible of delimitation by fixed metes and bounds." Weber v. Anheuser-Busch, Inc., 348 U.S. 468, 480 (1955).

761 Stat. 140 (1947), 29 U.S.C. $\$ 157$ (1958).

861 Stat. 140 (1947), 29 U.S.C. $\$ 158$ (1958).

9 E.g., Justice Burton states: "Our cases which hold that state jurisdiction is pre-empted are distinguishable. In them we have been concerned lest one forum would enjoin, as illegal, conduct which the other forum would find legal, or that state courts would restrict the exercise of rights guaranteed by the Federal Acts." UAW v. Russell, 356 U.S. 634, 644 (1958).

10356 U.S. 617 (1957). 
emption decisions for over a century. When Congress, acting in a field of dominant federal interest as part of a comprehensive scheme of federal regulation, confers rights and creates remedies with respect to certain conduct, it has expressed its judgment on the desirable scope of regulation, and state action to supplement it is as "conflicting," offensive and invalid as state action in derogation. ${ }^{11}$

The Garner case, upon which he relies, is the landmark decision in establishing the pre-emption doctrine in the labor relations field. ${ }^{12}$ The issue in that case concerned the validity of a state court injunction prohibiting organizational picketing issued pursuant to the Pennsylvania Labor Relations Act. The United States Supreme Court held that the conduct involved fell within the jurisdiction of the National Labor Relations Board and that Congress had pre-empted this area of labor relations.

The Garner case examines the reasons for the congressional decision to occupy certain segments of the labor relations field. The enactment of a comprehensive scheme of federal regulation is said to be justified by the need to avoid "diversities and conflicts" in this area, and the Supreme Court did not, of course, question the right of Congress to occupy all or any part of this field.

It would seem that Chief Justice Warren's reliance on Garner rests upon the following interpretation of the Court's decision:

1. Congress considered the field of labor relations in or affecting interstate commerce as involving a dominant federal interest requiring a national policy.

2. Full effect could not be given to that national policy unless differing local attitudes, laws and procedures were niade inapplicable to labor relations in or affecting interstate commerce.

3. Congress concluded that enactment of a comprehensive scheme of federal regulation would avoid these potential conflicts by making the local "attitudes, laws, and procedures" inapplicable to labor relations in industries in or affecting interstate commerce.

4. Congress further implemented its purpose when it created a special tribunal, the NLRB, with primary responsibility to interpret and apply the national labor policy. ${ }^{13}$

Thus, Garner is used by the Chief Justice in the broadest pre-emption sense, although it is conceded that those who advocate the "conflict of remedy" approach also find refuge in the language of the Garner opinion. Those who

11 Id. at 625 .

12 Garner v. Teamsters Union, 346 U.S. 485 (1953).

13 The Board's interpretive responsibility also includes a determination by the Board in the first instance of whether the issue comes within its jurisdiction. "The point is rather that the Board, and not the state court, is empowered to pass upon sucb issues in the first instance." Weber v. Anheuser-Busch, Inc., 348 U.S. 468, 478 (1955); reiterated by Chief Justice Warren, International Ass'n of Machinists v. Gonzales, 356 U.S. 617, 627 (1958). 
emphasize the conflict approach in that case, however, fail to distinguish between congressional action and the rationale for that action.

In some of his dissents Warren does discuss the possibility of conflict, but such references to conflict do not provide the test upon which his opinions turn. They are attempts to explain, from a defensive position, the justification for pre-emption. He views the majority opimion in such cases as a denial of the doctrine of complete pre-emption established by the Garner case.

In $U A W$ v. Russell, ${ }^{14}$ the Court allowed a state court to award damages for conduct regulated by the LMRA. ${ }^{15}$ In his dissent Chief Justice Warren unequivocally emphasized the congressional intent to create a uniform scheme of national labor relations, ${ }^{16}$ and argued that the majority opinion in the Russell case would frustrate this clear purpose. ${ }^{17}$ Again, in Youngdahl v. Rainfair, ${ }^{18}$ which allowed a state court to enjoin picketing enmeshed with violence or picketing that obstructed the free use of streets adjacent to the employer's business, he based his dissent squarely upon the exclusive jurisdiction of the NLRB over any conduct within the area to which its powers apply.

Against this backdrop, it is easier to understand the inevitability of his opinion in Guss v. Utah Labor Relations Bd., ${ }^{19}$ a decision that created a "no-man's land" in which the state courts could not act even though the NLRB would not. In that case there was no question that the conduct and parties involved were within the jurisdiction of the Board. However, as a result of discretionary jurisdictional standards set by the Board, the particular employer involved in the case was demed its services. It was argued that the Board's refusal to act made it possible for the state to regulate the labor activity. But the Chief Justice speaking for the majority of the Court, held that its refusal to take jurisdiction did not empower the state to act.

His approach to the problem posed in the Guss case had as its point of departure a recognition of the exclusive jurisdiction of the NLRB for regulating the conduct in question. Congress was said to have stripped the state courts and state boards, as well as federal courts, of power to regulate in this field. ${ }^{20}$ But could that exclusive jurisdiction be taken from the NLRB and returned to the states? Was refusal by the Board to take jurisdiction enough by itself to automatically revest the states with jurisdiction?

It is important to remember that the Chief Justice did not beheve the

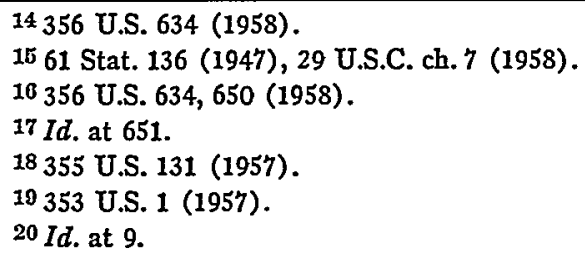


states had retained a reservoir of jurisdiction upon which they could draw. For a revesting of authority it was deemed necessary that Congress clearly express its intent to return authority to the states. Neither the Board nor the Court could supply this intent.

The Chief Justice relied for his conclusion on the LMRA and the legislative history of its pertinent sections. He found no positive evidence that the setting of jurisdictional standards would operate as a grant of authority to the states. Furthermore he found support for his Guss ruling in the proviso of section 10 (a): ${ }^{21}$ "We hold that the proviso to $\S 10$ (a) is the exclusive means whereby States may be enabled to act concerning the matters which Congress has entrusted to the . . . [NLRB]." ${ }^{22}$ Under the "exclusive means" provided by section 10 (a) the Board is required to enter into an agreement with the state agency in order to cede jurisdiction. There was no sucli agreement in this case or in its companion, Amalgamated Meat Cutters v. Fairlawn, Inc.; ${ }^{23}$ thus Chief Justice Warren found no revesting of jurisdiction in the state.

The most recent Supreme Court case concerning pre-emption in labor relations, San Diego Bldg. Trades Council v. Garmont, ${ }^{24}$ is consistent with much of the Chief Justice's position. Although giving some attention to "potential conflict" between state and federal authorities, Mr. Justice Frankfurter, writing for the majority, seems to apply a "conduct" test: "Our concern is with delimiting areas of conduct which must be free from state regulation if national policy is to be left unhampered."25 He reiterates the strong pre-emption doctrine originally stated in Garner:

But the unifying consideration of our decisions has been regard to the fact that Congress has entrusted administration of the labor policy for the Nation to a centralized administrative agency, armed with its own procedures, and equipped with its specialized knowledge and cumulative experience. ${ }^{26}$

Earlier it had been noted that the Chief Justice's complete pre-emption doctrine leaves an "easement" across the pre-empted area within which states can act without Board or congressional authority. ${ }^{27}$ In his dissenting opinion in the Russell case he stated:

It is clear from the legislative history of the Taft-Hartley Act that in subjecting certain conduct to regulation as an unfair labor practice Congress had no intention of impairing a State's traditional powers to punish

2161 Stat. 146 (1947), 29 U.S.C. \& 160(a) (1958). See note 22 infra.

22353 U.S. 1, 9 (1957).

23353 U.S. 20 (1957).

24359 U.S. 236 (1959).

25 Id. at 246.

$26 I d$. at 242.

27 See text following note 8 supra. 
or in some instances prevent that same conduct when it was offensive to what a leading case termed "such traditionally local matters as public safety and order and the use of streets and highways."28

Is the fact that Chief Justice Warren voted with the majority in United Constr. Workers v. Laburmum, ${ }^{29}$ upholding a state court award of damages, consistent with this narrow interpretation of reservation of state power? The majority opinion in Laburnum, written by Mr. Justice Burton, is a broader reservation of authority than that which the Chief Justice seems to concede. In his dissent in the Gonzales ${ }^{30}$ case, he criticizes the Court's use of Laburnum as a precedent. ${ }^{31}$ His dissent in the Russell case indicates that he joined with the majority in Laburnum because he thought the particular dispute was not a labor dispute and was thus outside the scope of conduct regulated by the act. ${ }^{32}$

There is at least one remaining important pre-emption problem that will probably come before the Court for decision. It arises out of the Guss case, ${ }^{38}$ where the Court created a "no-man's-land" in the field of labor relations. The Chief Justice, speaking for the Court, said, "Congress is free to change the situation at will." Congress did try to change this situation by enacting section 701(a) of the Landrum-Griffin amendments. ${ }^{35}$ Whatever Congress may have accomplished by this amendment, it failed to direct whether state or federal law is to apply in section 701(a) cases. In this area the pre-emption problem remains unsolved.

It has been stated that certain legislative history "has been generally regarded as conclusive proof that Congress intended to permit state courts and agencies to apply state law in those cases over which they are empowered by section 701 (a) to assert jurisdiction." that statement apparently is not certain of this conclusion; he suggests that

28356 U.S. 634, 647 (1957).

29347 U.S. 656 (1954).

30356 U.S. 617 (1957).

31356 U.S. 617, 632 n.22 (1958).

32356 U.S. 634,656 (1958).

33353 U.S. I (1957).

$34 I d$. at 11.

3573 Stat. 541 (1959), 29 U.S.C. \$ 164(c) (Supp. 1959).

"(1) The Board, in its discretion, may, by rule of decision or by published rules . . . decline to assert jurisdiction over any labor dispute involving any class or category of employers, where, in the opinion of the Board, the effect of such labor dispute on commerce is not sufficiently substantial to warrant the exercise of its jurisdiction: Provided, that the Board shall not decline to assert jurisdiction over any labor dispute over which it would assert jurisdiction under the standards prevailing upon August 1, 1959. (2) Nothing in this subchapter shall be deemed to prevent or bar any agency or the courts of any State or Territory ... from assuming and asserting jurisdiction over labor disputes over which the Board declines pursuant to paragraph (1) of this subsection, to assert jurisdiction." 36 Aaron, The Labor-Management Reporting and Disclosute Act of 1959, 73 HaRv. L.

REv. 1086, 1097 (1960). 
"a more.likely development is that state courts will be permitted to apply state law, federal law, or perhaps a combination of both."3r

It is likely that the Court may adopt what has been referred to as the "accordion theory" and hold that only federal law is to apply. ${ }^{38}$ This approach is predicated upon the fact that while section 701(a) prohibits the NLRB from declining jurisdiction over disputes coming within its jurisdiction through standards prevailing on August 1, 1959, it does not prevent the Board from expanding those standards. The Board has in the past both expanded and constricted its jurisdiction.

Congress did not, through section 701(a), exclude the NLRB from jurisdiction over any cases in or affecting interstate commerce. It simply provided an alternative forum for the handling of certain cases. Since the Board could at any time assert exclusive jurisdiction over cases as to which it had temporarily relinquished its authority, it is only common sense that the same law be applied to all cases in or affecting interstate commerce.

To hold otherwise would lead to incongruous results. For example, the California Supreme Court, in Petri Cleaners, Inc. v. Automotive Employees Local $88{ }^{30}$ held:

[E]mployers are not required by law to engage in collective bargaining and ... closed or union shop agreements and concerted activities to achieve them are lawful in this state whether or not a majority of the employees directly involved wish such agreements.

Thus, a California employer engaged in interstate commerce, but with a dollar volume below the Board's August 1, 1959, jurisdictional standards, could not be required by California law to engage in collective bargaining. But if his business should improve so that his dollar volume would bring

37 Id. at 1098.

38 "The "accordion theory' is predicated on the fact that section $701(\mathrm{c})$, while prohibiting the Board from declining in the future to assert jurisdiction over any labor dispute which it would have taken under the standards prevailing on August 1, 1959, does not proscribe a future expansion by the Board of its jurisdictional standards in effect on that date. Just as the Board broadened the scope of its jurisdiction in 1958, replacing standards in effect since 1954, so it may expand its jurisdiction again. On the other hand, the 1954 standards constricted those initiated in 1950, and this, too, may bappen again, so long as the statutory minimum is observed. Thus, subject to the limitations imposed by the statute, the Board's jurisdiction may be bikened to an accordion, which may be pulled out or pushed in as desired.

'Proponents of the 'accordion theory' argue, on the basis of these facts, that the Board never really relinquishes jurisdiction of any case or category of cases affecting commerce, since it retains the power at any time to change its pohicy and to assert the exclusive authority it has temporarily declined to exercise. From this premise it is but a short step to the conclusion that the field has been completely pre-empted by the federal government, and that in those proceedings in which state courts and agencies are currently permitted to act they may apply only federal law." Aaron, The Labor-Management Reporting and Disclosure Act of 1959, 73 Harv. L. REv. 1086, 1097-98 (1960).

3953 Cal. 2d 455, 2 Cal. Rptr. 470, 349 P.2d 76 (1960).

40 Id. at 474-75. 
him within the Board's jurisdiction, or if the Board should lower its jurisdictional standards to include him, then he could be required to engage in collective bargaining.

Also, under California law even a minority union could by concerted action force this same employer to sign a closed shop agreement. Again, this employer, as a result of increased business or Board action changing its standards, may suddenly flnd himself within the jurisdiction of the NLRB. Because the federal law outlaws the closed shop, he would thereby be a party to a contract containing an illegal union security clause. And the union might be found to have committed an unfair labor practice by engaging in concerted activities unlawful under federal labor policy.

It is this "accordion-like" movennent of federal jurisdiction triggered either by a change in the employer's dollar volume of business or by the Board's lowering its standards which will determine whether an einployer or the union is at any given time governed by state or federal labor law. Such occurrences will hardly provide for that stability of labor relations dictated by the federal labor policy.

It is difficult to imagine that Congress intended such disquieting results to flow from section 701(a). It is even inore difficult to imagine that the Supreme Court would find that Congress intended to introduce turmoil rather than stability in the area of labor relations. As Chief Justice Warren stated, "Because Congress did not in specific words make its will manifest ... we must be guided by what is consistent with the scheme of regulation that Congress has established." 41 And that is a scheme of regulation that seeks to establish uniformity of policy and stability of labor relations in those industries engaged in interstate cominerce.

Giving effect to this scheme inevitably led to the application of the preemption doctrine to the field of labor relations. Would this not necessarily include the application of federal labor law, no matter what tribunal or forum, state or federal, services the units of industry in or affecting interstate commerce?

Regardless of how the section 701(a) problem may finally be determined, it is clear that in the already decided cases the Chief Justice lias consistently adopted a theory of complete pre-emption. With the exception of a reservation of power, by the states to protect "public safety and order," his opinions decisively make conduct within the authority of the NLRB the basic test for the application of the pre-emption doctrine. "Conflict of remedy" is not the decisive test. The question to be answered is, "Does the conduct which the state is attempting to control come within that area which is regulated by the NLRB?" If so, pre-emption applies, thus ousting state jurisdiction.

41 UAW v. Russell, 356 U.S. 634,647 (1958). 
When the majority has applied the pre-emption doctrine he has voted with them without being overly concerned as to the theory on which preemption was based. When the majority, arguing from a conflict of remedy theory, has refused to apply the doctrine of complete pre-emption, he has dissented, ${ }^{42}$ unless he has found defendant's conduct outside the scope of federal control, as he did in Laburnum. ${ }^{43}$

\section{II}

\section{FIRST AMENDMENT AND LABOR CASES}

In two important Supreme Court labor decisions, International Bhd. of Teamsters v. "Vogt" and United States v. UAW, ${ }^{45}$ Chief Justice Warren concurred with Justice Black, in dissents written by Douglas. The important similarity between these cases, which was undoubtedly controlling for the Chief Justice, was that both turned upon an interpretation and an application of the first amendment. Well known for his stand on first amendment rights, it was to be expected that he would dissent from both of Frankfurter's majority opinions.

The Vogt case involved an issue which had been the subject of a series of cases beginning in 1949 with Senn v. Tile Layers Union: ${ }^{46}$ To what extent is peaceful picketing a right of free speech protected by the first amendment? In Senn, the Supreme Court hinted that it considered peaceful picketing a protected right: "Members of a union might, without special statutory authorization by a State, make known the facts of a labor dispute, for freedom of speech is guaranteed by the Federal Constitution." 47

Senn was followed by Thornhill $v$. Alabama, ${ }^{48}$ which clearly established that the dissemination of information concerning the facts of a labor dispute was an exercise of free speech. As such it was within the protection of the first amendment and, under the fourteenth amendment, could not be abridged by state action.

In later cases, the Supreme Court gradually narrowed the area in which it would apply the Thornhill doctrine. The first amendment was held not to prevent a state from enjoining acts of picketing in themselves peaceful when they were enmeshed with violent conduct; ${ }^{40}$ when the state decided

42 E.g., International Ass'n of Machinists v. Gonzales, 356 U.S. 617 (1958); Youngdahl v. Rainfair, 355 U.S. 131 (1957); UAW v. Russell, 356 U.S. 634 (1957); UAW v. Wisconsin Employment Relations Bd., 351 U.S. 266 (1956).

43 United Constr. Workers v. Laburnum Constr. Corp., 347 U.S. 656 (1954).

44354 U.S. 284 (1957).

45352 U.S. 567 (1957).

46301 U.S. 468 (1937).

47 Id. at 478.

48310 U.S. 88 (1940).

49 Milk Wagon Drivers, Local 753 v. Meadowmoor Dairies, Inc., 312 U.S. 287 (1941). 
that the picketers were outside the area of the dispute $;^{50}$ or when the picketing was an essential part of a course of conduct in violation of a state policy which was admittedly valid. ${ }^{51}$ On the basis of this last ruling, in United Ass'n of Journeymen Plumbers \& Steamfitters v. Graham, ${ }^{52}$ it was held that if a state had a "right to work" law, this statement of public policy gave it the right to enjoin picketing which sought to induce a violation of that law. The Graham decision was rendered just prior to the Chief Justice's appointment to the bench. Had he participated in the decision, he undoubtedly would have joined Justices Douglas and Black in dissenting, as he did in the Vogt case. ${ }^{53}$

Vogt involved a Wisconsin statute prohibiting picketing in the absence of a labor dispute, and also prohibiting anyone from coercing, intimidating or inducing any employer to interfere with any of his employees in the enjoyment of their legal rights. Stranger pickets carried placards reading "The men on this job are not $100 \%$ affiliated with the A.F.ofL." ${ }^{54}$ The court held that the fourteenth amendment did not limit the power of the state to enjoin such picketing.

As the dissent pointed out, ${ }^{55}$ the facts of the Vogt case are difficult to distinguish from those of an earlier case, $A F L$ v. Swing, wherein the Court reached the opposite result. ${ }^{56}$ Neither involved violence; both involved stranger picketing. The only conclusion that can be drawn is that the position of the Supreme Court had changed substantially since its consideration of the Sreing case.

In his dissent, Justice Douglas states that the majority decision returns to the situation that existed prior to the Senn case. He asserts that the only valid test is that expressed in Giboney v. Empire Storage \& Ice Co.:57 "[T]his form of expression can be regulated or prohibited only to the extent that it forms an essential part of a course of conduct which the State can regulate or prohibit." 58 Douglas did not think Vogt met that test: "But where, as here, there is no rioting, ... no fisticuffs, no coercion-indeed nothing but speech-the principles announced in Thornwill and Swing should give the advocacy of one side of a dispute First Amendment protection. ${ }^{959}$

50 Carpenters \& Joiners Union v. Ritters Cafe, 315 U.S. 722 (1942).

51 Building Serv. Employees Int'I Union v. Gazzam, 339 U.S. 532 (1950); International Bhd. of Teamsters v. Hanke, 339 U.S. 470 (1950) ; Giboney v. Einpire Storage \& Ice Co., 336 U.S. 490 (1949); Hughes v. Superior Court of California, 339 U.S. 460 (1950).

52345 U.S. 192 (1953).

53 354 U.S. 284, 295 (1957).

54 Id. at 285 .

65 Id. at 296.

58312 U.S. 321 (1941).

57336 U.S. 490 (1949).

58354 U.S. 284, 297 (1957).

58 Id. at 296. 
Undoubtedly the Chief Justice joined the dissent because of his abiding belief in the sanctity of the first amendment. This position becomes even more clear in the $U A W$ case. ${ }^{60}$ There the majority failed to find a constitutional question in the absence of certain findings of fact. But the dissent, in which the Chief Justice joined, considered these questions of fact irrelevant and argued that the act "as construed and applied, is a broadside assault on the freedom of political expression guaranteed by the First Amendment." ${ }^{11}$ The majority's concern over protecting the rights of a minority by allowing an mfringement of the first amendment was characterized as "burning down the house to roast the pig."

Again, the Chief Justice's position on this case stems from his views on the first amendment. The result of the case would have been the same regardless of the parties involved. As Justice Douglas said:

The principle at stake is not peculiar to unions. It is applicable as well to associations of nuanufacturers, retail and wholesale trade groups, consumers' leagues, farmers' unions, religious groups and every other association representing a segment of American life and taking an active part in our political campaigns and discussions. It is as inmortant an issue as has come before the Court, for it reaches the very vitals of our system of government. ${ }^{63}$

That Chief Justice Warren applies this principle regardless of the group involved is supported by his stand in Sweezy v. New Hampshire, ${ }^{04}$ which involved a state investigative committee and a lecture at a university. In that case he stated:

Our form of government is built upon the premise that every citizen shall have the right to engage in political expression and association. The riglit was enslurined in the First Amendment of the Bill of Rights. ${ }^{65}$

We do not now conceive of any circumstance wherein a state interest would justify infringement of rights in these fields. ${ }^{66}$

Chief Justice Warren apparently did not believe that the state public policy involved in Vogt was a "state interest" sufficient to "justify infringement" of the "right enshrined in the First Amendment." Nor did he find in the $U A W$ case a compelling national policy which justified curtailing the "right to engage in political expression."

\section{III}

THE COLLECTIVE BARGAINING PROCESS AND THE COLLECTIVE AGREEMENT

In recent years the Supreme Court has taken several opportunities to expound its view on the collective bargaining process and the nature of the

60 United States v. UAW, 352 U.S. 56 (1957).

61 Id. at 598.

62 Id. at 596 .

63 Id. at 593 .

64354 U.S. 234 (1957).

65 Id. at 250 .

66 Id. at 251. 
collective bargaining agreement. ${ }^{67}$ This has been a period of learning for the Court itself. Thus, a number of its opinions in this area have contained expressions not pertinent to the specific issue to be decided and comments which do not reflect the real world of labor relations.

Although the Chief Justice has voted with the majority in cases dealing with this area of the law, he has not, himself, written any of the basic opinions. Nor are his specific views on labor relations easily found in his other decisions. His expressions on the collective bargaining process have been indirect. For example, his view of the national labor policy incorporates an acceptance of collective bargaining and of the trade umion as an integral part of that process.

In his opinion it is implicit in our national labor policy that trade unions must not be rendered meffective or destroyed as an institution. Thus in his dissent in $U A W$ v. Russell, , $^{8}$ he says: "By reason of vicarious hability for its members' ill-advised conduct on the picket hines, the union is to be subjected to a series of judgments that may and probably will reduce it to bankruptcy, or at the very least deprive it of the means necessary to perform its role as bargaining agent of the employees it represents." ${ }^{69}$ Moreover, trade unions are of prime importance as the bargaining agents in the collective bargaining process. The national labor policy with reference to collective bargaining requires their existence.

Some insight into Chief Justice Warren's views of the collective bargaining process itself is gained from another statement he made in his dissent in Russell. He said, "I can conceive of nothing more disruptive of congenial labor relations than arming employees, union and management with the potential for 'sinarting' one another with exemplary damages. ${ }^{\prime \prime 70}$ His use of the word "congenial" is the key to the Chief Justice's attitude toward labor relations. He refers to "congenial" labor relations, a description that we daresay has never before been used to characterize them.

Thus, the Chief Justice believes that labor relations should be carried on in a sympathetic atmosphere of agreeableness, pleasantness, cooperation, and as he said in his nessage to the California Legislature in 1953, "characterized by a spirit of good will." It is his abiding view that indus-

67 United Steelworkers of America v. Enterprise Wheel \& Car Corp., 363 U.S. 593 (1960); United Steelworkers of America v. Warrior \& Gulf Nav. Co., 363 U.S. 574 (1960); United Steelworkers of America v. American Mfg. Co., 363 U.S. 564 (1960); NLRB v. Insurance Agents Int'1 Union, 361 U.S. 477 (1960). See Kagel, Enterprise, Warrior and Gulf, American Manufactursing and Arbitration, to be published in the 1961 ProceEdngs of the National Academy of ARBitrators, by the Bureau of National Affairs.

e8 356 U.S. 634, 647 (1958).

69 Id. at 658 .

$70 I d$. at 653 .

71 Address by Earl Warren, Governor, to the California Legislature in Joint Convention, January 5, 1953. 1 Cal. S. Jour., 1st Reg. Sess. 35, 40 (1953). 
trial peace will be achieved when the parties have a "better understanding ... of the other fellow's problem," 72 and when "people ... appreciate the common benefits to be derived from open and honest labor-management relationships."73

Certainly Chief Justice Warren believes that the climate within which the collective bargaining process is to be carried on should not be marked by animosity. And clearly he is of the firm opinion that the Court should not lend itself to either creating or continuing frictions which would result in rekindling "animosity," prolonging "bitterness" and keeping "old wounds open." " Such action by the Court would hardly lead to "congenial" labor relations.

If a controversy does not seem to require a "congenial" climate, then the Chief Justice may fail to see it as a labor dispute that comes within the scope of the LMRA. Thus in discussing the Laburnum stranger picketing situation ${ }^{75}$ in his dissenting opinion in Russell he said: "There was no prospect of a continuing relationship between the parties to the suit, and no need for concern over the climate of labor relations that an action might impair."76

One of the objectives sought through the collective bargaining process is the collective agreement. With the adoption of section 301 of the TaftHartley $\mathrm{Act}^{77}$ such an agreement is a contract that can be sued upon.$^{78}$ The Court's decisions dealing with this section have been of prime importance.

Section 301 was put to its first important test in Employees $v$. Westinghouse Corp. ${ }^{78}$ where a inajority of the Court held that a union could not sue on behalf of an employee's wage claim arising under a collective bargaining agreement. Chief Justice Warren, in a very brief concurring opinion, joined with the majority in holding that the union could not sue on the wage claim, but only on the basis that the claim was a "uniquely personal right" of the employee. ${ }^{80}$

It is extremely doubtful that such a distinction should have been recognized. Protection of the integrity of the agreement, i.e., that its terms should be observed with respect to the individuals covered by it, is also a "right"

72 Message by Earl Warren, Governor, to the California Legislature in Joint Convention, January 3, 1949. 1 Cal. S. Jour., 1st Reg. Sess. 32, 37 (1949).

73 Message of Earl Warren, Governor, to the California Legislature in Joint Convention, January 8, 1945. 1 Cal. S. Jour., 1st Reg. Sess. 23, 25 (1945).

74356 U.S. 634,654 (1958).

75 See text at note 29 supra.

76356 U.S. 634,656 (1958).

7761 Stat. 156 (1947), 29 U.S.C. $\$ 185$ (1958).

78 Ibid. "Suits for violation of contracts between an employer and a labor organization representing employees . . or between any such labor organizations, may be brought ...."

79348 U.S. 437 (1955).

$80 \mathrm{Id}$. at 461 . 
of the union as one of its signators. And the union should be permitted to sue on this right as it sought to do in Westinghouse.

The important aspect of the Westinghouse case was Justice Frankfurter's effort to have section 301 characterized as a procedural rather than as a substantive provision of the Taft-Hartley Act. ${ }^{81}$ If declared procedural, state law could be used in the application of section 301; if substantive, then only federal law could be applied. The Chief Justice, $m$ his concurring opinion, made it clear that he saw no need to decide the question stressed by Justice Frankfurter and based his decision solely on the nature of the "uniquely personal rights" for which the union was not the proper party to bring the suit. Later, when the issue of characterizing section 301 as procedural or substantive was clearly before the Court in Textile Workers Union v. Lincoln Mills of Alabama ${ }^{82}$ the Chief Justice joined the majority in holding that section 301 was substantive.

The clear result of Lincoln Mills was to provide for the specific enforcement of collective bargaining agreements by means of a federal common law to be fashioned by the federal courts based upon the national labor policy. This view fits in completely with the Chief Justice's high regard for observing the national labor policy, whatever it may be, and for avoiding the differing policies of the states in this area.

Since Lincoln Mills, lie has voted to hold that the collective bargaining agreement is enforceable and entitled to specific performance. ${ }^{83}$ In the Sand Door case, ${ }^{84}$ joiming in a dissenting opinion written by Justice Douglas, $^{85}$ the Chief Justice also gave approval to enforcing the collective bargaiming agreement even if its enforcement involved a practice which has apparently been disapproved by the Court: "Enforcing the collective bargaining agreement-standing by its terms-is not one of the coercive practices at which the Act was aimed. Enforcement of these agreements is conducive to peace. Disregard of collective agreements-the flouting of them-is disruptive." 186 Thus Chief Justice Warren is part of the Court which is developing important legal sanctions for one of the primary objectives of the collective bargaining processes-the collective agreement.

The parties to the collective bargaining relationship have developed various techniques which they use in the collective bargaining process to settle their differences. These techniques include negotiation, arbitration,

81 Ibid.

82353 U.S. 448 (195').

83 United Steelworkers of America v. Enterprise Wheel \& Car Corp., 363 U.S. 593 (1960); United Steelworkers of America v. Warrior \& Gulf Nav. Co., 363 U.S. 574 (1960); United Steelworkers of America v. American Mfg. Co., 363 U.S. 564 (1960).

84 Local 1976, Carpenters v. NLRB, 357 U.S. 93 (1958).

85 Id. at 111 .

86 Id. at 112 . 
economic pressures, political and legal action. The Chief Justice approves of a greater opportunity for peaceful picketing without state interference than does the majority of the Court, as is demonstrated by his joining the dissent in International Bhd. of Teamsters v. Vogt, Inc. ${ }^{87}$

In $N L R B$ v. Insurance Agents Int'l Union, ${ }^{88}$ he joined with the majority in approving the use of the partial strike while negotiations were in progress. Justice Brennan, speaking for the Court, stated that the presence of economic weapons in reserve and their actual exercise on occasion by the parties "is recognized as part and parcel of the system that the Wagner and Taft-Hartley Acts" have created. It must have been this emphasis upon the national labor policy that appealed to the Chief Justice. Permitting the use of harassing tactics such as on-the-job-partial-strikes during negotiations can hardly be considered the basis for "congenial" labor relations.

He also joined with the majority in NLRB v. Truck Drivers Union No. $449,{ }^{89}$ which permitted temporary lockouts to preserve the multi-employer bargaining process from the disintegration threatened by a union's strike action. He was undoubtedly persuaded by the majority's argument that the Taft-Hartley Act gives "statutory recogmition that there are circumstances in which employers may lawfully resort to the lockout as an economic weapon," of the comprehensive scheme of regulation found in the act, is the best judge of those circumstances in which a lockout may lawfully be used to balance conflicting legitimate interests. ${ }^{91}$

Although the Chief Justice recognizes that the parties to the collective bargaining process have available, and sometimes use, economic weapons, he is decisive in his view that the Court should not add to or unduly enhance these techniques. Thus, in $U A W v$. Russell,,$^{22}$ he almost sarcastically emphasizes that "The parties to labor controversies have enough devices for making one another 'smart' without this Court putting its stamp of approval upon another." 93

From actions during his terms as Governor of the State of California we know that this admomition apphied equally to the state legislature. He criticized any attempts at "legislative counter attacks of management and labor against each other," might stir up animosity between labor and management," "95 and in 1953

87354 U.S. 284,295 (1957).

88361 U.S. 477 (1960).

89353 U.S. 87 (1957).

80 Id. at 92,93 .

91 Id. at 97 .

82356 U.S. 634 (1957).

Q3 Id. at 653 .

94 See note 74 supra.

95 Ibid. 
commended the legislature for not enacting "punitive or retaliatory legislation" in the labor relations field..$^{96}$

Thus, it can be seen that Chief Justice Warren accepts the collective bargaining process within the framework of national labor policy, recognizes the trade union as an integral and indispensable part of that process, hopes for a "congenial" climate for labor-management relations in which "animosity" and "friction" will be reduced to a minimun, and condemns any action by court or legislature that "disrupts" the delicate balance required for a continumg relationship "characterized by a spirit of good will" and understanding.

\section{IV}

\section{GENERAI CHARACTERISTICS}

Certain pervasive characteristics of the Chief Justice's approach to law have undoubtedly been the basis for a large number of his decisions in labor cases. His strong support of pre-emption can be explained in part by his firm adherence to the doctrine of separation of powers. If a matter is within the area of congressional authority then Congress must act upon it. It is not for the Court to act in its place.

In Guss v. Utah Labor Relations Board, ${ }^{97}$ he chose to rule in favor of a no-nan's land rather than to invade the area of legislative authority. "Since Congress' power in the area of commerce among the States is plenary, its judgment must be respected whatever policy objections there may be to creation of a no-man's-land." bench, he addressed himself to Congress, placing upon it the responsibility for action: "Congress is free to change the situation at will." Consistent with this approach is a statement by Justice Douglas in the Sand Door dissent, ${ }^{100}$ jomed by Chief Justice Warren:

We act today more like a Committee of the Congress than the Court. We strain to outlaw bargaining contracts long accepted, long used. Perhaps these particular provisions have evils in them that should be declared contrary to the public interest. They are, however, so much a part of the very fabric of collective bargaining that we should leave this policy-making to Congress .....101

When a matter has been delegated to an agency by Congress, the Chief Justice feels that it is not for courts to usurp that delegation. "The point

80 See note 72 supra.

97353 U.S. 1 (1957).

$98 \mathrm{Id}$. at I1.

99 Ibid.

100357 U.S. 93 (1958).

101 Id. at 114-15. 
is rather that the Board, and not the state court, is empowered to pass upon such issues." ${ }^{102} \mathrm{He}$ also considers the admonition equally applicable to the Supreme Court. ${ }^{103}$ As an administrator, Warren undoubtedly realized that effective administration and government can only be achieved with clearly defined areas of authority. This, coupled with what appears to be a sincere belief in the limited functions of the judiciary, has prevented him from operating like a "Committee of Congress."

Perliaps in his long career as an administrator can also be found the source for his direct approach to a problem. This matter-of-fact, down-toearth attitude expresses itself in relatively brief, simply constructed decisions. His decisions are not filled with the almost Proustian digressions characteristic of some Justices. He appears to make an effort to write a decision which will be sufficiently clear to settle the matter and to provide a basis for future action.

The Chief Justice tends not to give effect to legalistic technical distinctions that fall short of practical meaning. In his dissent in International Ass'n of Machinists v. Gonzales, ${ }^{104}$ he said "presence or absence of preemption is ... not a game that is played with labels or an exercise in artful pleading. ${ }^{105} \mathrm{He}$ also joined in a Douglas dissent refusing to give meaning to a technical distinction on which the majority based its case: "The present decision is capricious. The boycott is lawful if the employer agrees to abide by this collective bargaining agreement. It is unlawful if the employer reneges." 108

His decisions in the labor field do not decide more than that which is required by the issue. He does not use a case as a vehicle for establishing labor policy or for consideration of constitutional issues not raised by the facts. In Employees v. Westinghouse Corp. ${ }^{107}$ le concurs in the decisions of the majority, but on very narrow grounds of statutory interpretation, saying, "Thus viewed, it becomes unnecessary for us either to make labor policy or to raise constitutional issues."108 Justice Frankfurter in writing the majority opinion had, in the Chief Justice's view, taken the opportunity to raise a constitutional issue not required by the facts. But in Textile Workers $v$. Lincoln Mills of Alabama ${ }^{109}$ where the issue was raised by the facts, lie concurred in Justice Douglas's majority opinion, making it clear that he disagreed with Justice Frankfurter and agreed with Justice Douglas

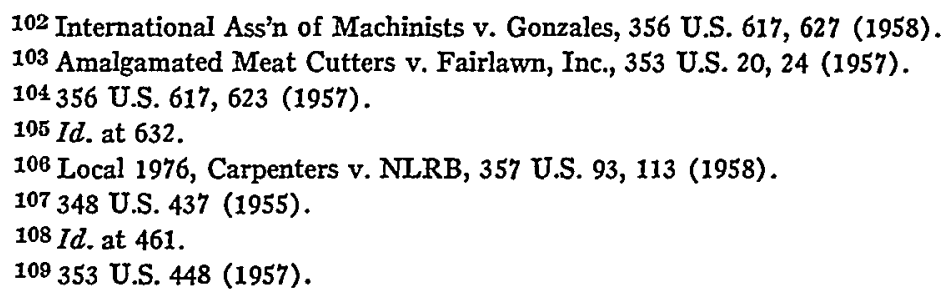


on the issue of whether section 301 of the Taft-Hartley Act was a substantive provision. The Chief Justice's refusal to go further than required by the issues of the case is apparently a conscious refusal. Writing in 1955, he said, "They [the courts] are kept in line not only by the words of the Constitution, but by a tradition of self-restraint and impersonality." 110

Chief Justice Warren has also demonstrated self-restraint. The requirement of impersonality is met to some extent by his nonpartisan approach. In his California career, prior to joining the bench, he had managed to create an image of nonpartisanship. Never a strong spokesman for any particular group, he was able to gain the support of many groups and in 1946 won both the Democratic and Republican nominations for governor. Although not all nonpartisans adopt the same approach, the lack of identification with specific large interest groups provides an opportunity for identification with the rights of individuals and minority groups. And there is no doubt that he has been a strong supporter of such rights, as demonstrated by his stand on the first and fifth amendments and on the desegregation issue.

In view of this nonpartisan image, it is difficult to give credence to statements or implications that Chief Justice Warren is pro-labor. In reality, he would be for pre-emption in the labor law area regardless of who urged it. Voting for pre-emption can hardly be called pro-labor, although it may show a pro-federal position. His stand on the first amendment can hardly be called pro-labor since he protects the same rights as diligently in relation to any group or individual. If it must be termed pro-something, it is proConstitution. Nor can he be considered pro-labor for voting with the majority in the cases which deal with the collective bargaining process and the collective agreement, for he was there applying what he believed to be national labor policy in a manner consisent with his view of separation of powers. Perhaps this approach should be termed pro-Congress.

The Chief Justice's approach to labor cases is based upon the broad principles heretofore discussed, tempered by practical reality and a desire for a concrete resolution of the issue. All his decisions are, and will be, consistent with his view that one of the reasons why "the next mid-century challenges to the law must be met is simply this: the nature of man. In all times and places he has had a sense of justice and desire for justice. Any child expresses this or that 'isn't fair.' A legal system is simply a mature and sophisticated attempt, never perfected, but always capable of improvement, to institutionalize this sense of justice and to free men from the terror and unpredictability of arbitrary force."111 